\author{
NANAEKE \\ Indonesian Journal of Early Childhood Education \\ Volume 3, Nomor 2, Desember 2020
}

\title{
IMPLEMENTASI POLA ASUH ORANG TUA DALAM MENANAMKAN NILAI MORAL ANAK USIA DINI
}

\author{
Husnul Hidayah \\ Jurusan Pendidikan Islam Anak Usia Dini \\ Fakultas Tarbiyah dan Keguruan, UIN Alauddin Makassar \\ E-mail: Husnulhidayah011@gmail.com \\ M. Yusuf T. \\ Jurusan Pendidikan Islam Anak Usia Dini \\ Fakultas Tarbiyah dan Keguruan, UIN Alauddin Makassar \\ E-mail: yusuftahir@uin-alauddin.ac.id \\ Besse Marjani Alwi \\ Jurusan Pendidikan Islam Anak Usia Dini \\ Fakultas Tarbiyah dan Keguruan, UIN Alauddin Makassar \\ E-mail: marjanialwi@gmail.com
}

\begin{abstract}
Abstrak
Penelitian ini bertujuan: (1) untuk mengetahui bagaimana pola asuh orang tua dalam menanamkan nilai moral anak usia dini (2-6 tahun) dalam keluarga di Desa Kindang Kabupaten Bulukumba, (2) Untuk mengetahui faktor penghambat orang tua dalam menanamkan nilai moral anak usia dini (2-6 tahun) dalam keluarga di Desa Kindang Kabupaten Bulukumba, (3) Untuk mengetahui pola asuh yang efektif dalam menanamkan nilai moral anak usia dini (2-6 tahun) dalam keluarga di Desa Kindang Kabupaten Bulukumba. Penelitian ini merupakan penelitian kualitatif deskriptif. Sumber data sebanyak 6 orang tua yang memiliki anak usia 2-6 tahun. Teknik pengumpulan data menggunakan observasi, wawancara, dan dokumentasi. Hasil penelitian menujukkan bahwa: 1) pola asuh orang tua dalam menanamkan nilai moral pada anak memiliki karakteristik yang berbedabeda, dan terlihat campuran dari 5 (lima) orang tua dalam keluarga 2 (dua) diantarannya mengarah pada pola asuh campuran antara pola asuh otoriter dan demokratis. Dan 3 (tiga) keluarga lainnya mengarah pada pola asuh demokratis dan permisif, namun permisif disini tidak mutlak. Sedangkan 1 (satu) orang tua dalam keluarga mengarah pada pola asuh permisif dan otoriter. 2) faktor penghambat orang tua dalam menanamkan nilai moral pada anak adalah: a) faktor gadget. b) faktor lingkungan yang kurang kondusif, sehingga orang tua sering kali khawatir terhadap perkembangan moral anak, c) faktor hubungan antara suami dan istri yang menyebabkan kurangnya memperhatikan perkembangan anak terutama perkembangan moralnya, dan, d) faktor pendidikan orang tua yang rendah sehingga kurang memahami apa yang menjadi kebutuhan bagi perkembangan anak mereka. 3) pola asuh yang efektif dalam menanamkan nilai moral pada anak dalam keluarga yakni pola asuh otoriter dan pola asuh demokratis.
\end{abstract}

Kata Kunci: Anak Usia Dini, Nilai Moral, Pola Asuh 


\begin{abstract}
This study aims (1) to find out how parenting in instilling the moral value of early childhood (2-6 years old) on Kindang village families at Bulukumba District, (2) to find out the inhibiting factors of parents in instilling the moral values of early childhood (2-6 years) on Kindang village families at Bulukumba District, (3) to find out the effective parenting in instilling the moral values of early childhood (2-6 years) on Kindang village families at Bulukumba District. This study was descriptive research. Data collected with observation, interviews, and documentation. The results showed that: 1) parenting in instilling moral values in early childhood on Kindang village families have different characteristics. There were two of five parents in a family lead to mixed parenting between authoritarian and democratic parenting. Authoritarian parenting is characterized by a strong attitude in educating children and forcing the will of children. The other three families lead to democratic and permissive parenting. While one parent in the family leads to permissive and authoritarian parenting. 2) Inhibiting factors of parents in instilling moral values in children were: a) gadget factors, b) less conducive environment c) the relationship between husband and wife that caused lack of attention to children moral development, d) parents education 3) the effective parenting in instilling the moral values of early childhood on families of Kindang village were authoritarian and democratic parenting.
\end{abstract}

Keywords: Early Childhood, Moral Values, Parenting

\title{
PENDAHULUAN
}

Pendidikan merupakan upaya yang berkaitan dengan pengembangan berbagai aspek kepribadian yang mendorong dan mempengaruhi anak untuk berbuat atas kesadaran, kemauan, dan tanggung jawabnya. Pendidikan bersifat mutlak dalam kehidupan baik dalam kehidupan keluarga, masyarakat, maupun dalam kehidupan berbangsa (Susanto, 2015:1). Pendidikan selalu berkenaan dengan upaya pembinaan manusia, karena itu keberhasilan pendidikan sangat bergantung pada unsur manusianya yang menjadi penentu akan berhasil atau tidaknya sebuah pendidikan.

Undang-undang Nomor 20 Tahun 2003 Tentang Sistem Pendidikan Nasional Pasal 1 angka 14 menyatakan bahwa pendidikan anak usia dini (PAUD) adalah suatu upaya pembinaan yang ditujukan pada anak sejak lahir sampai usia enam tahun yang dilakukan dengan melalui pemberian rangsangan pendidikan untuk membantu pertumbuhan dan perkembangan jasmani dan rohani, agar anak memiliki kesiapan dalam memasuki pendidikan lebih lanjut (Menteri Pendidikan Nasional, 2009:1) baik pendidikan secara formal di sekolah maupun secara nonformal.

Anak usia dini merupakan masa dimana anak dalam masa peka, karena pada masa ini merupakan masa terjadinya pematangan fungsi-fungsi fisik dan psikis yang siap merespon stimulasi lingkungan dan menginternalisasikan ke dalam 
pribadinya. Masa ini merupakan masa awal pengembangan kemampuan fisik, kognitif, bahasa, sosial emosional, konsep diri, disiplin, kemandirian, seni, moral, dan nilai-nilai agama. Oleh karena itu dibutuhkan kondisi dan stimulus yang sesuai dengan kebutuhan anak agar pertumbuhan dan perkembangannya tercapai secara optimal (Mutiah, 2010:1).

Pendidikan anak usia dini yang dilakukan dalam keluarga disebut dengan pendidikan informal karena pendidikan tersebut dilakukan di dalam lingkungan keluarga. Dalam keluarga terjadi proses pembudayaan dari orang tua kepada anak tentang pengenalan secara dini untuk mengenal sesama anggota dalam lingkungan yang diikuti tentang pembinaan nilai-nilai serta norma-norma yang berlaku dalam lingkungan masyarakat. Diantara unsur-unsur terpenting yang akan menentukan corak kepribadian seseorang di kemudian hari adalah nilai-nilai yang diambil dari lingkungan, terutama keluarga sendiri (Amilin, 2015).

Pendidikan anak usia dini sangat bermanfaat bagi pembentukan perilaku dan cara berfikir seorang anak dalam masa perkembangan untuk mempersiapkan anak dalam menghadapi lingkungan dan juga jenjang pendidikan yang selanjutnya mampu memberikan kesempatan anak untuk bereksplorasi yang selalu berada dalam pengawasan dan arahan (Tahir, Ismawati, Rismayani, \& Nurhikmah, 2018:66).

Keberhasilan pertumbuhan dan perkembangan seorang anak dapat dihubungkan dengan perkembangan sikap dan pribadi orang tuanya serta hubungan komunikasi dan role model dalam keluarganya serta stimulasi dan pola asuh yang diberikan orang tua dalam keluarganya (Damayanti, Nurhasanah, Nurafia, \& Kamal, 2019:29). Dimana keluarga merupakan tempat pertama anakanak mendapatkan pendidikan, dari orangtua dan anggota keluarga lainnya, selain itu keluarga merupakan tempat untuk mendapatkan sebuah kenyamanan, kasih sayang, cinta dan juga pembelajaran keteladanan (Susylowati, 2018:1).

Pendidikan yang diberikan anak dalam keluarga merupakan tugas orangtua yang harus dilaksanakan dan dijalankan dengan baik sehingga mendapatkan hasil didikan yang di inginkan. Oleh karena itu peran orang tua dalam mengasuh dan mendidik anak sangat mempengaruhi perilaku anak. Namun, tidak semua orangtua memiliki kesamaan dalam mengambil keputusan dan sikap karena setiap orang tua memiliki karakteristik yang berbeda-beda terutama dalam mengasuh anak.

Setiap anak memiliki keunikan dalam arti pola pertumbuhan dan perkembangan baik kepribadian, gaya pembelajaran dan latar belakang keluarga yang berbeda-beda. Pembelajaran pada anak usia dini adalah hasil dari interaksi antara pemikiran anak dan pengalamannya dengan materi-materi, ide-ide, dan reprensentasi mentalnya tentang dunia sekitarnya.

Keluarga merupakan tempat untuk mendapatkan sebuah kenyamanan, kasih sayang, cinta dan juga pembelajaran keteladanan (Susylowati, 2018). Dalam hal ini keluarga berperang penting dalam perkembangan dan pertumbuhan moral anak. 
Pola pengasuhan yang diterapkan dalam keluarga harus benar-benar dipahami sebelum menerapkannya pada anak, karena pola didikan yang diberikan pada anak akan sangat menentukan karakter atau perilaku anak kedepannya.

Sasaran pendidikan bukan hanya soal kecerdasan dalam hal ilmu pengetahuanm, melainkan juga moral atau tingkah laku, nilai, serta perilakuperilaku yang mencerminkan sikap moralitas lainnya. Perilaku moral perlu ditanamkan sejak dini pada anak agar sikap moralitas tertanam dalam dirinya, sehingga ketika dewasa ia mampu merealisasikan dirinya terhadap norma-norma yang berlaku dalam lingkungan keluarga maupun masyarakat.

Khaironi dalam Dahlia, dkk mengatakan Pendidikan moral yang dilaksanakan sejak dini bukanlah suatu usaha yang tiada berguna, moral yang baik berasal dari lingkungan yang bermoral baik, karena lingkungan yang baik menjadi sumber bagi anak dalam berperilaku sesuai dengan nilai-nilai yang berlaku. Anak bermoral dihasilkan melalui proses yang dilalui setiap hari dalam pembinaan moral yang baik, seperti dalam membedakan perilaku baik-buruk, benar-salah, sopan-tidak sopan (Damayanti dkk., 2019:9).

Penempatan nilai-nilai moral sebagai acuan utama bagi anak untuk memiliki kontrol diri secara internal akan senantiasa merujukkan diri anak pada nilai-nilai moral (Shochib, 2014:23). Kontrol internal merupakan kontrol diri yang digunakan anak dalam mengarahkan perilakunya. Sehubungan dengan itu, upaya orang tua dalam menanamkan moral anak untuk mentaati dan memiliki perilaku atau normanorma yang berlaku dalam masyarakat.

Pengontrolan moral secara interal pada dasarnya mengupayakan anak-anak untuk berperilaku yang sadar akan nilai-nilai moral. Belajar berperilaku moral yang diterima oleh lingkungan sekitar merupakan proses yang lama dan lambat, tetapi dasar-dasarnya yang diletakkan sejak dini, maka itulah kode yang membimbing perilakunya bila telah menjadi besar nanti (Susanto, 2011:66).

Berdasarkan uraian diatas maka adapun rumusan masalah dalam penelitian ini adalah bagaimana pola asuh orang tua dalam menanamkan nilai moral anak usia dini (2-6 tahun) dalam keluarga di Desa Kindang Kabupaten Bulukumba. Adapun tujuan penelitian ini adalah 1) untuk mengetahui bagaimana pola asuh orang tua dalam menanamkan nilai moral anak usia dini (2-6 tahun) dalam keluarga di Desa Kindang Kabupaten Bulukumba, 2) Untuk mengetahui faktor penghambat orang tua dalam menanamkan nilai moral anak usia dini (2-6 tahun) dalam keluarga di Desa Kindang Kabupaten Bulukumba, (3) Untuk mengetahui pola asuh yang efektif dalam menanamkan nilai moral anak usia dini (2-6 tahun) dalam keluarga di Desa Kindang Kabupaten Bulukumba.

\section{METODE PENELITIAN}

Penelitian ini adalah penelitian kualitatif deskriptif. Subjek dalam penelitian ini sebanyak 6 orang tua yang memiliki anak usia 2 sampai 6 tahun. penelitian ini 
dilakukan di Desa Kindang Kabupaten Bulukumba sejak awal februari sampai dengan pertengahan bulan maret 2020. Data dikumpulkan dengan mengunakan observasi, wawancara dan dokumentasi. peneliti melakukan pengamatan lapangan dengan mengumpulkan informasi yang diperlukan selain itu peneliti mengadakan wawancara terstruktur dengan membuat daftar pertanyaan yang akan diajukan kepada responden, peneliti juga menggunakan teknik dokumentasi guna untuk mengumpulkan data-data terkait hasil temuan. Setelah data sudah dikumpulkan kemudian dianalisis menggunakan analisis deskriktif dengan menggunakan 3 (tiga) tahap yakni reduksi data (mengumpulkan data dan informasi penting dari hasil observasi, wawancara dan dokumentasi), penyajian data (rangkuman deskriktif dari hasil reduksi data untuk memudahkan dalam memahami rencana kerja selanjutnya), penarikan kesimpulan (menguji kesimpulan dengan membandingkan teori yang relevan, mengecek ulang hasil temuan, serta membuat kesimpulan berupa temuan).

\section{HASIL DAN PEMBAHASAN}

Berdasarkan hasil penelitian yang dilakukan pada 5 (lima) orang tua dalam keluarga di Desa Kindang Kabupten Bulukumba dari 5 (lima) orang tua, 2 (dua) diantaranya mengarah pada pola asuh campuran antara otoriter dan demokratis. Sedangkan 3 (tiga) lagi diantaranya mengarah pada pola asuh demokratis dan permisif.

\section{Pola Asuh Orang Tua dalam Menanamkan Nilai Moral pada Anak}

\section{a. Pola Asuh Otoriter dan Demokratis}

Pola asuh otoriter ditandai dengan adanya kekerasan dalam mendidik anak, orang tua yang selalu memaksakan kehendak terhadap anak. Terlihat pada keluarga I (Ibu Hs) dan orang tua pada keluarga II (Ibu Rs) yang menerapkan antara pola asuh otoriter dan demokratis. Hal ini ditandai dengan adanya kekerasan dalam mendidik anak, memukul, mencubit dan memaksakan kehendaknya terhadap anak. sedangkan pola asuh demokratis ditandai dengan orang tua yang memberikan nasehat secara lembut terhadap anak. memberitahu ketika apa yang dilakukan anak tidak sesuai dengan aturan dalam keluarga.

\section{b. Pola Asuh Demokratis dan Permisif}

Pola asuh demokratis ditandai dengan adanya pemberian nasehat, menerima atau menghargai pendapat anak. pada keluarga III (Ibu Nr), keluarga V (Ibu Ar), dan Keluarga VI (Ibu Ft) yang mengarah pada pola asuh demokratis dan permisif namun permisif disini tidak mutlak. Pola asuh demokratis ditandai dengan memberikan nasehat kepada anaknya ketika berbuat salah dan mendidik anak dengan mengajarkannya mandiri, meminta pendapat anak (berdiskusi) ketika hendak memutuskan sesuatu. Sedangkan pola asuh permisif ditandai dengan orang tua yang tidak memberikan hukuman kepada anak ketika berbuat salah hanya saja

74 NANAEKE - Indonesian Journal of Early Childhood Education, Vol. 3, No. 2, Desember 2020 
menasehatinya.

\section{c. Pola Asuh Permisif dan Otoriter}

Pola asuh permisif adalah pola asuh yang permisif adalah pola asuh yang memberikan kebebasan terhadap anak tanpa adanya arahan atau pengawasan yang cukup. Sedangkan pola asuh otoriter adalah pola asuh yang bersifat keras dalam mendidik anak. pada keluarga IV (Ibu Hm) dalam menanamkan nilai moral pada anak mengarah pada pola asuh permisif dan juga otoriter hal ini dilihat dari sikapnya yang memberikan kebebasan terhadap anak dalam bermain dan berrgaul bersama teman lainnya, meninggalkan anaknya seharian yang kadang dititip ke tetangga atau neneknya. Sedangkan pola asuh otoriter disini ditandai dengan sikap orang tua yang kadang mencubit anaknya ketika menangis di tempat keramaian.

Berdasarkan hasil penelitian yang dilakukan oleh Amilin dalam penelitiannya yang berjudul Pola Asuh Orang Tua dalam Menanamkan Nilai Moral Agama pada Anak, (keluarga buruh tani di desa karangcegak kecamatan kutasari kabupaten purbalingga), menunjukkan bahwa pola asuh orang tua dalam menanamkan nilai moral agama pada anak menerapkan pola asuh yang berbeda-beda sesuai dengan pengetahuan orang tua dan kondisi masing-masing-masing keluarga. Dari 5 (lima) keluarga, 3 (tiga) diantaranya mengarah pada pola asuh permisif. Sedangkan 2 (dua) keluarga diantaranya menggunakan pola asuh campuran antara pola asuh demokratis dan pola asuh otoriter. Pola asuh demokratis dilihat dari adanya keterbukaan orang tua kepada anak, pola asuh demokratis dinisi ditandai dengan adanya taklim (memberitahu), targhib (motivasi), uswatun khasanah (teladan), bil hikmah (bijaksana) dan adanya musyawarah (diskusi). Sedangkan pola asuh otoriter ditandai dengan adanya tahrim (larangan) namun otoriter disini tidak mutlak hanya sebatas melarang terhadap hal-hal yang kurang baik seperti tidak boleh meninggalkan sholat, berkata tidak sopan. Sedangkan pola asuh permisif dapat dilihat dari sikap orang tua yang membiarkan segala tindakan anak, memberikan kebebasan terhadap anak, pada keluarga ini tidak terdapat taklim (memberitahu), targhib (motvasi), tahrim (larangan), uswatun khasanah (teladan) bil hikmah (bijaksana), dan musyawarah (diskusi).

\section{Faktor Penghambat Orang Tua dalam Menanamkan Nilai Moral pada Anak}

Adapun faktor yang menjadi penghambat orang tua dalam menanamkan nilai moral pada anak diantaranya:

\section{a. Lingkungan Yang Kurang Kondusif}

Salah satu faktor yang menjadi penghambat orang tua dalam menanamkan nilai moral pada anak adalah lingkungan yang kurang kondusif sebagian orang tua merasa faktor lingkungan menjadi penghambat bagi mereka dalam menanamkan nilai moral pada anak.

Pada keluarga II (Ibu Rs), keluarga III (Ibu Nr), dan keluarga VI (Ibu Ft) menganggap bahwa faktor yang menjadi penghambat dalam menanamkan nilai 
moral pada anaknya adalah faktor lingkungan mereka khawatir akan dampak buruk yang didapat oleh anak, seperti anak meniru perilaku teman-temannya saat berbicara tidak sopan, berbicara kotor, dan perilaku buruk lainnya. Padahal mereka ketika dirumah mengajarkan anak yang baik-baik.

\section{b. Faktor Gadget/Teknologi}

Semakin berkembangnya teknologi sekarang sebagian orang tua khawatir terhadap anaknya yang sudah mengetahui cara mengaplikasikan gadget/ handphone karena fiturnya yang disukai anak adalah game dan youtube. Pada keluarga I (Ibu Hs) menganggap bahwa salah satu faktor yang menjadi penghambat baginya adalah faktor gadget/handphone karena anaknya yang sudah ketagihan bermain game dan youtube, ketika anaknya ditegur untuk berhenti bermain ia kadang memberontak dan menangis katika ia diganggu. Karena pada umumnya anak yang menghabiskan waktunya dengan gadget akan lebih emosional, pemberontak karena merasa sedang diganggu saat asyik bermain game atau nonton youtube.

\section{c. Faktor Hubungan Antara Suami dan Istri dan Faktor Pendidikan Rendah}

Hubungan yang kurang harmonis antara suami dan istri juga mempengaruhi dalam memberikan pendidikan kepada anak. Dimana orang tua yang sering cekcok dan memperlihatkan perilakunya kepada anak, maka anak akan merasa tertekan dan merasa sedih serta besar kemungkinan anak juga akan meniru perilaku orang tuanya dengan apa yang mereka lihat. Pada keluarga IV (Ibu Hm) yang merasa bahwa hubungan yang kurang harmonis dengan suaminya mengakibatkan suaminya yang kurang peduli terhadap perkembangan anaknya terutama dalam moralnya yang acuh tak acuh, Ibu $\mathrm{Hm}$ juga merasa rendahnya faktor pendidikan yang ia alami sehingga ia kurang memahami dalam mendidik anak.

Penelitian yang dilakukan oleh Amilin pada penelitiannya yang berjudul Pola Asuh Orang Tua dalam Menanamkan Nilai Moral Agama pada anak, menunjukkan bahwa faktor penghambat orang tua dalam menanamkan nilai moral agama pada anak dilatar belakangi oleh, 1) latar belakang pendidikan orang tua, dari hasil penelitian yang dilakukan oleh Amilin pendidikan orang tua menjadi salah satu penyebab terhambatnya orang tua dalam menanamkan nilai moral agama pada anak, rendahnya pendidikan dan kesadaran orang tua akan pentingnya pendidikan mengakibatkan orang tua acuh tak acuh, kurangnya pengetahuan orang menjadi salah satu faktor yang menghambat orang tua dalam mendidik dan membimbing anak sesuai dengan nilai-nilai moral yang berlaku. 2) faktor kedua yaitu kesibukan orang tua, 3) lingkungan yang kurang kondusif, salah satu faktor penghambat orang tua adalah faktor lingkungan, seperti anak meniru teman-temannya saat berbicara tidak sopan, padahal dirumah orang tua mengajarkan anaknya untuk berperilaku baik. 


\section{Pola Asuh yang Efektif dalam Menanamkan Nilai Moral pada Anak}

Pola asuh orang tua adalah interaksi orang tua dan anak, dimana orang tua memberikan dorongan bagi anak dengan mengubah tingkah laku anak menginginkan anak memiliki perilaku atau perbuatan yang baik atau terpuji. Orang tua dalam keluarga di Desa Kindang Kabupaten Bulukumba mereka memiliki pola asuh yang berbeda-beda dalam mendidik anak terutama dalam menanamkan nilai moral pada anak.

\section{a. Pola Asuh Otoriter}

Dapat dilihat keluarga I (Ibu Hs), keluarga II (Ibu Rs), dan keluarga IV (Ibu Hm) yang mendidik anaknya dengan sikap yang berubah-ubah, sikap ke anaknya tergantung dari perilaku anak jika anaknya tidak menuruti atau mendengarkan apa yang dikatakan ibunya maka ia tidak segang untuk memarahi bahkan kadang memukul/mencubit anaknya. Anak yang di didik dengan sikap otoriter sedikit juga akan mengubah perilaku anak yang tadinya anak tidak mau mendengarkan perkataan orang tuanya, dengan sikap otoriter yang diterapkan anak akan menurut dan mendengarkan. Meskipun pola asuh otoriter besar sangat mempengaruhi perkembangan dan pertumbuhan anak. tetapi pola asuh otoriter juga memberikan dampak positif.

\section{b. Pola Asuh Demokratis}

Keluarga III (Ibu Nr), keluarga V (Ibu Am), dan keluarga VI (Ibu Ft) dalam menanamkan nilai moral kepada anaknya menggunakan pola asuh demokratis sebagai pola asuh yang efektif dalam perkembangan moral anak. menurut Ibu Nr dalam mendidik anak terutama dalam perkembangan moralnya kita harus bersikap yang lembut terhadap anak karena besar kemungkinan anak akan meniru sikap/perbuatan kita, jika sikap kita buruk ke anak maka anak bisa saja menirunya ketika dewasa nanti. Sedangkan Ibu Am mengatakan bahwa dalam mendidik anak kita harus sabar karena anak adalah titipan dari Allah, kita harus mendidiknya dengan agama sabaarnya juga harus yang tegas agar anak mendengar. Sedangkan Ibu Ft beranggapan bahwa anak itu tidak boleh dimarahi tapi dinasehati lbu Ft juga dalam mendidik anak tidak membatasi anak bermain maupun bergaul bersama temannya (sikapnya menunjukkan sedikit permisif).

Orang tua yang mendidik anak dengan pola asuh demokratis akan berdampak baik bagi perkembangan dan pertumbuhan anak, anak yang terbiasa di didik dengan sikap yang tegas tidak kasar akan menjadikan anak yang di didik akan tumbuh menjadi anak yang bermoral, bertanggung jawab, dan memiliki nilainilai yang baik dalam masyarakat, karena anak yang di didik secara demokratis sedari dini terbiasa dengan perilaku-perilaku yang baik yang sudah ditanamkan sejak dini oleh orang tuanya. 


\section{KESIMPULAN}

Berdasarkan uraian diatas penulis dapat menyimpulkan bahwa pola asuh orang tua yang mendekati yang dapat menanamkan nilai moral anak dengan baik adalah pola asuh demokratis dimana anak diperhatikan, diberi nasehat dengan memberitahu, berdiskusi kepada anak sebelum memutuskan sesuatu, dan mengajarkan anak tentang hal-hal yang positif dan menegur secara halus ketika anak melakukan sesuatu yang tidak sesuai dengan aturan keluarga yang disepakati.

Adapun yang menjadi penghambat orang tua dalam menanamkan nilai moral anak diantaranya adalah faktor lingkungan yang kurang kondusif disebabkan orang tua khawatir anaknya akan meniru perilaku-perilaku buruk seperti, berkata kotor (tidak sopan). Pola asuh yang efektif dalam menanamkan nilai moral anak adalah pola asuh demokratis, orang tua memperhatikan kebutuhan-kebutuhan anak, memberikan nasehat yang lembut, tegas dalam menghadapi anak bukan berarti keras. Pola asuh otoriter juga sedikit memberikan positif bagi anak tidak mau mendengarkan orang tuanya, seperti menegur anak dengan intonasi suara yang sedikit keras, otoriter disini tidak mutlak hanya sebatas memberikan teguran kepada anak jika sudah beberapa kali di nasehati tetapi belum maun mendengarkan.

\section{DAFTAR PUSTAKA}

Amilin. (2015). Pola Asuh Orang Tua Dalam Menanamkan Nilai Moral Agama Pada Anak: Studi Pada Keluarga Buruh Tani Di Desa Karangcegak, Kecamatan Kutasari, Kabupaten Purbalingga. Skripsi. Fak. IImu Pendidikan UNY.

Damayanti, E., Nurhasanah, N., Nurafia, N., \& Kamal, E. E. (2019). Deteksi Dini Pencapaian Perkembangan Anak Usia 2-3 Tahun Berdasarkan Standar Nasional Pendidikan Anak Usia Dini. NANAEKE: Indonesian Journal of Early Childhood Education, 2(1), 10-24.

Khaironi, M. (2017). Pendidikan Moral Anak Usia Dini. Universitas Hamzanwandi. Jurnal Golden Age Universitas Hamzanwandi, 1(1). Diambil dari http://ejournal.hamzanwandi.ac.id/dspace/handle/1

Menteri Pendidikan Nasional. (2009). Peraturan Pemerintah Dinas Pendidikan Nasional, Undang-undang Republik Indonesia Nomor 58 Tahun 2009 tentang Standar Pendidikan Anak Usia Dini.

Mutiah, D. (2010). Psikologi Bermain Anak Usia Dini. Jakarta: Prenada Media Group.

Peraturan Pemerintah Dinas Pendidikan Nasional. (2009). Undang-undang Republik Indonesia Nomor 58 Tahun 2009 tentang Standar Pendidikan Anak 
Usia Dini. Jakarta: Sinar Grafika

Susanto, A. (2011). Perkembangan Anak Usia Dini; pengantar dalam berbagai aspeknya. Jakarta: Pranada Media Group.

Susanto, A. (2015). Bimbingan \& Konseling Di Taman Kanak-Kanak. Jakarta: Pranada Media Group.

Shochib, M. (2014). Pola Asuh Orang Tua dalam Membantu Anak Mengembangkan Disiplin Diri. Jakarta: PT. Rineka Cipta.

Susylowati. (2018). Pola Asuh Orang Tua Dalam Menanamkan Akhlak Pada Anak Sejak Dini: studi kasus TK Bakti Nusa Indah, Ciputan Timur, Tangerang Selatan Banten. Skripsi. Fak. IImu Tarbiyah dan Keguruan, UIN Syarif Hidayatullah.

Tahir, M. Y., Ismawati, Rismayani, \& Nurhikmah. (2018). Manajemen Kurikulum Anak Usia Dini pada Taman Kanak-kanak Aulia Samata Kabupaten Gowa. NANAEKE: Indonesian Journal of Early Childhood EducationIndonesian Journal Of Early Childhood Education, 1(1). 